\title{
Mundo da Metodologia: fundamentos da metodologia da pesquisa através da DGBL
}

\section{World of Methodology: research methodology fundamentals through DGBL}

\author{
MÁRCIO DA CUNHA MARINS \\ Centro Universitário Uniftec/FGV - Caxias do Sul
}

EVANDRO MANARA MILETTO

Instituto Federal de Educação, Ciência de Tecnologia do Rio Grande do Sul - IFRS - Campus Porto Alegre

Resumo: O presente artigo analisa a validade e as contribuições do jogo Mundo da Metodologia como instrumento facilitador para a aprendizagem dos fundamentos que tangem a composição dos objetivos de uma pesquisa, principalmente o que envolve a compreensão e diferenciação entre os conceitos de objetivos geral e específicos dentro de uma pesquisa científica. Para tal, a pesquisa se apoiou em um quase-experimento realizado em duas instituições de ensino superior, permitindo constatar que o game Mundo da Metodologia ultrapassou a finalidade de contribuir para a consolidação das bases teóricas exploradas por ele, oportunizando aos alunos a fazê-lo de forma clara, divertida e engajadora, mesmo para os jogadores não habituais.

Palavras-chave: DGBL. Aprendizagem Baseada em Jogos Digitais. Educação. Metodologia da Pesquisa.

\begin{abstract}
This paper analyzes the validity and contributions of the game World of Methodology as a facilitating tool for learning the fundamentals that affect the composition of the objectives of a research, specially that involves understanding and differentiation between the concepts of general and specific objectives within a scientific research. To achieve this goal, this research was based on a quasi-experiment carried out in two different higher education institutions, allowing to verify that World of Methodology exceeded its purpose of enabling the students to consolidate the theoretical bases explored throughout the game, providing them the opportunity to do it in a clear, fun and engaging way even for non-regular players.
\end{abstract}

Keywords: DGBL. Digital Game-Based Learning. Education. Research Methodology. 


\section{Introdução}

A ideia de um ensino despertado pelo interesse do aluno, segundo Antunes (2012), vem fazendo com que os jogos ganhem um espaço como ferramenta ideal da aprendizagem ao ajudar o aprendente a construir novas descobertas e desenvolver níveis diferentes de experiências enriquecedoras, transformando, definitivamente, o sentido do que se entende por material pedagógico. A evolução do brincar na sociedade humana em dimensões lúdicas e educativas é um dos aspectos citados por Alves (2007) que consolidam o jogo, enquanto instrumento de aprendizagem, como uma alternativa metodológica bastante pesquisada e empregada nas últimas décadas.

Lima e Moita (2011) ressaltam, porém, que os impactos provocados pela rápida evolução tecnológica acabaram por estabelecer novas formas de ensino apoiadas em um conjunto diversificado de recursos que favorecem a inclusão da multimídia no processo de ensinoaprendizagem. Nesse sentido, um dos enfoques se refere à utilização dos jogos digitais como uma ferramenta didática, visto que este recurso permite ao aluno adquirir conhecimento ao mesmo tempo que se diverte e desenvolve suas habilidades.

O processo de ensino-aprendizagem mediado pelos jogos digitais é destacado por Chagas (2018) como uma estratégia que se apropria de mecanismos de engajamento presentes nos jogos para resolver problemas práticos no âmbito educacional. Ao adotá-la, as instituições de ensino retomam o lúdico que é reservado a poucos momentos nos anos finais da educação básica, bem como reduzem a segmentação da educação que é notada nos anos finais do ensino médio - justificando, assim, sua ampla utilização no ensino profissionalizante e superior em todo o mundo.

A partir desse contexto, o presente artigo propõe analisar a validade e as contribuições do jogo Mundo da Metodologia como um instrumento digital facilitador no processo de ensinoaprendizagem dos fundamentos que tangem a composição e estruturação dos objetivos de uma pesquisa. Faz-se importante ratificar, entretanto, que o game em questão foi desenvolvido com a finalidade de apoiar disciplinas no ensino superior que requerem a compreensão e diferenciação dos conceitos de objetivos geral e específicos - princípios estes que, de acordo com Oliveira (2011), representam a totalidade do problema a ser respondido em um projeto científico e, dessa forma, precisam ter uma construção clara e concisa.

A hipótese levantada para este estudo é de que a aplicação do jogo Mundo da Metodologia pode contribuir significativamente com o processo de aprendizagem ao proporcionar uma dinâmica divertida e engajadora para o entendimento das bases teóricas exploradas por ele, dentro da disciplina de Metodologia da Pesquisa.

O artigo está estruturado da seguinte forma: nas seções 2 e 3, são apresentados os referenciais teóricos para fundamentar o projeto; na seção 4, apresenta-se o jogo Mundo da Metodologia, bem como as bases para o seu desenvolvimento; na seção 5, são apresentadas as ligações do jogo com os preceitos teóricos que se deseja com ele explorar; na seção 6, apresentase a metodologia que guiou a condução do estudo; na seção 7, são apresentados os resultados do experimento prático; e na seção 8 são colocadas as considerações finais do presente estudo.

\section{Os jogos e sua ludicidade}

Conforme explica Alves (2006), a presença dos jogos na história da humanidade tem início com a própria evolução do homem, quando já conferiam aos rituais da caça e da guerra um caráter lúdico, de entretenimento, de força e poder. Nessa linha, Huizinga (2000) evidencia que, desde a Grécia Antiga, é na intensidade, no poder de fascinação e na capacidade de excitar que residem a essência e as características primordiais do jogo, fazendo da inter-relação entre a competição e a ludicidade uma forma encontrada pelas mais distintas esferas da sociedade para exprimirem sua interpretação da vida e do mundo. 
Os jogos são descritos por Carvalho (2015) como contextos estruturados formados por regras bem definidas, nos quais os jogadores possuem objetivos e desafios claros. Tal cunho contextual, como afirmam Macedo, Petty e Passos (2007), é o que torna o ato de jogar um convite à descentração, posto que as regras, quando conhecidas por todos, agem como um regulador das ações entre os participantes. Antunes (2017), por sua vez, entende que as interações dentro das regras fazem parte de um imprescindível controle de relações interpessoais, por mais que um jogo estimule a flexibilidade de pensamento e possua intenções lúdicas.

É importante ressaltar que o componente lúdico dos jogos é destacado por Huizinga (2000) pelo seu notável papel ao provocar a expressão de elementos que envolvem a magia e o mistério, a honra e a dignidade, os sonhos de heroísmo e os primeiros passos das artes e da lógica, ultrapassando o pleno desenvolvimento das necessidades humanas inatas. Além da significativa contribuição para a formação de uma base cognitiva, emocional e social, Aguiar (2008) também evidencia que as atividades lúdicas impactam diretamente na obtenção de repertórios conceituais fundamentais do indivíduo, tendo, assim, distinto reflexo nas suas aquisições acadêmicas futuras.

Cid (2017) considera que o lúdico proporcionado pelos os jogos contribui para uma aprendizagem mais dinâmica e interessante. O uso dos jogos não apenas transforma o abstrato em concreto como viabiliza um aprendizado mais significativo sem que haja a imposição unilateral de conteúdos. Ao colocar os discentes frente a decisões de problemas reais, o uso dos jogos torna o ambiente de aula incentivador e interativo.

\section{Os jogos na educação e a aprendizagem baseada em jogos digitais}

Na perspectiva de Costa (2010), uma das principais razões pelas quais a educação se utiliza dos jogos é o seu inegável papel como agente emocional e motivador. Ao oportunizar a imersão em uma verdadeira experiência de aprendizagem, o emprego dos jogos, conforme apontam Boler e Kapp (2018), proporciona a cada indivíduo vivências personalizadas na esfera educacional, seja no âmbito mais simples da memorização ou na revisitação dos conteúdos aprendidos - panorama que consolida os jogos como uma alternativa viável em comparação à abordagem expositiva.

Não se pode deixar de destacar que Alves (2014) salienta que os diferentes ritmos e formas de processar novas informações são preocupações permanentes quando se trata do desenvolvimento de soluções engajadoras. Carvalho (2015), no entanto, explica que a integração bem-sucedida dos jogos nas mais variadas metodologias pedagógicas reside na sua adaptabilidade para pessoas de perfis e faixas etárias distintas - motivo, inclusive, que leva Antunes (2012) a classificar os jogos, em seu sentido integral, como um eficiente meio estimulador das múltiplas inteligências humanas. Para Moita (2017), através da contextualização, o jogo possibilita que conceitos considerados inicialmente difíceis - como ocorre comumente na matemática e na física - acabem tendo sua compreensão facilitada, justificando a inserção deste recurso no cotidiano dos alunos, em níveis diversificados.

Ainda que o universo dos games tenha trazido expressivos impactos positivos para o ambiente educacional, Kensky (2003) constata que o avanço das tecnologias, bem como o acesso a elas, fez surgir uma geração inteira de nativos digitais que está desencadeando um forte movimento externo às instituições de ensino, influenciando-as a implementar ações que atendam às expectativas desses alunos. Cid (2017), por sua vez, se refere a essa intensiva ampliação de iniciativas de conversão das escolas em espaços propensos à fluência digital como um marco de descontinuidade gradual dos jogos analógicos para dar lugar a um processo de ensinoaprendizagem instrumentalizado pelos games eletrônicos.

Uma das abordagens que vem ganhando força com a crescente utilização dos jogos digitais por crianças e adultos em diferentes conjunturas, de acordo com Chagas (2018), é a digital game-based learning (DGBL ou aprendizagem baseada em jogos digitais), uma estratégia que combina as mecânicas de entretenimento presentes nos games com as dinâmicas de aprendizagem que compreendem os campos cognitivo (engajamento intelectual), afetivo (imersão e diversão) e comportamental (incentivo a atitudes proativas), buscando concretizar 
experiências de forma agradável, acessível, significativa e contextualizada, seja no ambiente virtual ou real.

Segundo Mattar (2010), a DGBL está fundamentada na premissa de que os alunos mudaram sua forma de construir conhecimento e na de que pertencem a uma geração que experienciou profundamente, enquanto crescia, uma nova forma de jogar: através de computadores e videogames. Isso não somente elucida porque a DGBL consegue atingir toda uma nova massa de aprendizes como denota a gradativa descontinuidade de parte das antigas teorias sobre como as pessoas pensam e aprendem, já que os jogos eletrônicos permitem às pessoas desenvolver a capacidade de deduzir as regras pela observação, ao mesmo tempo em que manipulam sistemas complexos.

Aliás, o poder de simplificar o complexo a partir de uma representação da realidade é trazido por Alves (2014) como um aspecto em comum entre a aprendizagem, as tecnologias e os jogos. O reflexo do mundo real dentro do game faz com que o jogador compreenda os acontecimentos em seu contexto. Todavia, é a remoção de alguns elementos da realidade que faz o jogador se manter focado na essência do jogo, oferecendo a ele a possibilidade de análise entre a relação de causa e efeito em um prazo que não seria possível fora do mundo digital. A abstração da realidade é o que o torna o game fascinante, ajudando a reduzir sensivelmente o tempo necessário de aprendizado.

Na visão de Mattar (2010), os jogos eletrônicos assemelham-se ao modo como a nova geração aprende, favorecendo a aplicação da DGBL em atividades de revisão ou de aprendizado efetivo de diversos temas. Contudo, Schlemmer e Lopez (2017) propõem que tal abordagem pode ser exponencialmente amplificada quando associada a dispositivos mobile, mídias sociais, realidade aumentada ou espaços híbridos ${ }^{1}$.

\section{Mundo da Metodologia: uma aventura pelos conceitos introdutórios de Metodologia da Pesquisa}

Produzido em 2015 como um projeto da disciplina de Tecnologias de Informação e Comunicação, dentro do Mestrado Profissional em Informática na Educação do IFRS - Campus de Porto Alegre, o Mundo da Metodologia (Figura 1) é um jogo eletrônico do gênero de aventura, desenvolvido no estilo de plataforma². Disponível na versão desktop, o jogo visa apoiar o ensinoaprendizagem da disciplina de Metodologia da Pesquisa, no ensino superior, facilitando a compreensão do conceito de objetivos, dentro de um estudo científico, diferenciando o objetivo geral dos específicos.

\footnotetext{
1 Para Schlemmer e Lopez (2017), o espaço híbrido equivale às dinâmicas em que os atores agem e interagem em plataformas analógicas, físicas e/ou digitais com outros atores humanos ou não humanos, simultaneamente. Para eles, a DGBL pode envolver contextos de hibridismo, abrindo múltiplas possibilidades de participação e avaliação.

2 Segundo Marinacci (2012), os jogos de plataforma são aqueles em que evolução do jogador é linear e o protagonista deve avançar em uma direção, pulando para evitar obstáculos e explorar cenários, colecionando moedas e poderes especiais para derrotar vilões ao longo do caminho. O autor cita os jogos Sonic e Super Mario Bros. como exemplos desta modalidade.
} 
Figura 1 - Imagens do Jogo Mundo da Metodologia.
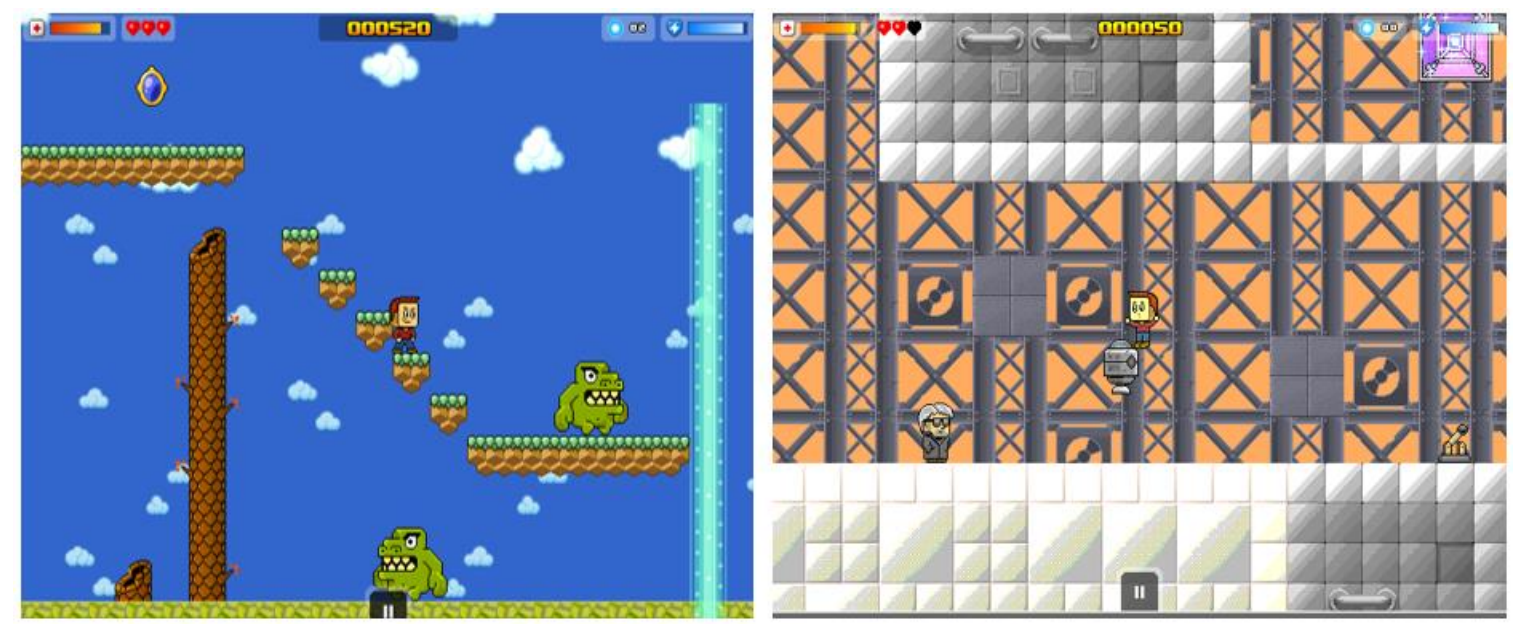

Fonte: telas do jogo no Sploder, capturadas pelos autores.

Através de uma premissa muito simples, a aplicação do Mundo da Metodologia busca potencializar a assimilação dos referidos conceitos em qualquer esfera acadêmica em que estes se façam necessários. Para proporcionar um melhor entendimento acerca da dinâmica e dos pilares que direcionaram a criação do jogo, são abordados a seguir os seguintes elementos: construção e acesso; sinopse e a ligação com conceitos introdutórios de metodologia da pesquisa; mecanismos; e comandos.

\subsection{Construção e acesso}

O jogo Mundo da Metodologia foi desenvolvido utilizando o Sploder ${ }^{3}$ (Figura 2), uma plataforma web de criação que permite, de forma online e gratuita, a construção, hospedagem e compartilhamento de jogos eletrônicos em diversas modalidades, entre elas: jogos de plataforma, labirintos e quebra-cabeças.

Figura 2 - Imagens do Jogo Mundo da Metodologia.

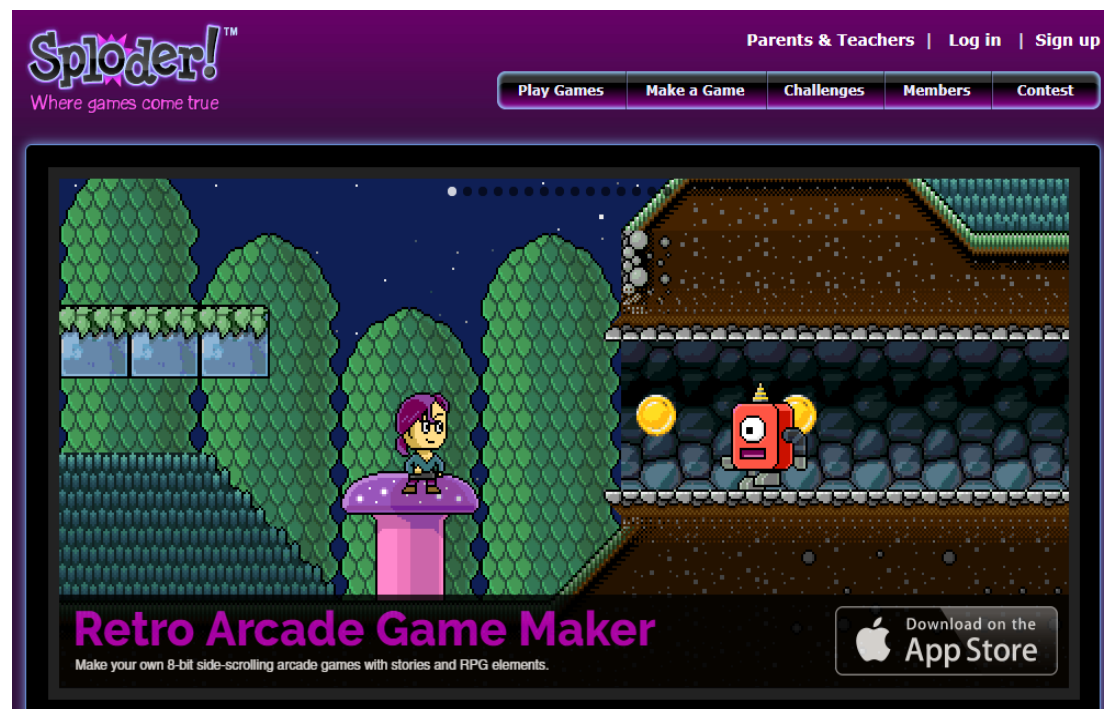

Fonte: tela do Sploder na Web, capturada pelos autores.

\footnotetext{
3 Disponível em: http://www.sploder.com.
} 
Provido de ferramentas simples e intuitivas, o Sploder dispensa qualquer conhecimento em linguagem de programação, permitindo que qualquer pessoa se torne um desenvolvedor de games. Além disso, essa plataforma de criação funciona como um grande repositório de jogos eletrônicos, facilitando o compartilhamento destes com usuários de todo o mundo, sejam eles desenvolvedores/jogadores cadastrados no site ou não. Nesse sentido, o Mundo da Metodologia segue as mesmas regras de compartilhamento, tendo seu acesso aberto ${ }^{4}$ a toda comunidade virtual, com fins educacionais e não lucrativos.

\subsection{Sinopse}

Ao longo de sua jornada, o jogador irá se deparar com uma série de perigos e obstáculos. Porém, ele contará com a ajuda do Mago Metodológico, um sábio que possui a missão de orientálo quanto às tarefas, tesouros perdidos e desafios guardados pelo caminho.

\subsection{Estrutura}

Ao acessar o endereço do jogo, o jogador se depara com uma tela na qual ele poderá optar por clicar em dois botões, conforme mostra a Figura 3. O botão "menu" o levará a uma outra tela na qual ele poderá: dar o seu voto para o jogo de acordo com seu grau de satisfação com o mesmo; verificar as melhores pontuações realizadas por outros jogadores; acessar jogos produzidos por outros desenvolvedores; ou voltar à tela que o permite iniciar a partida.

Figura 3 - Tela iniciais do Mundo da Metodologia.

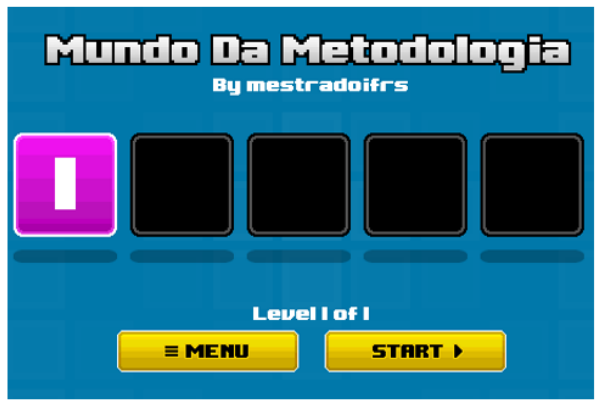

TELA INICIAL

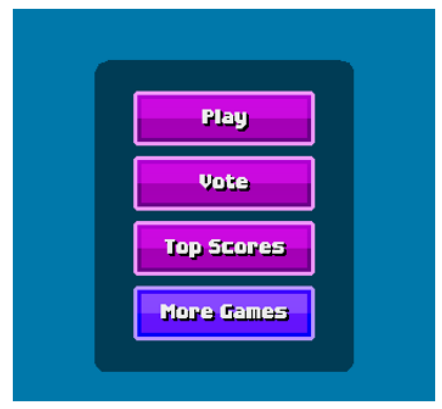

MENU DE OPÇÕES

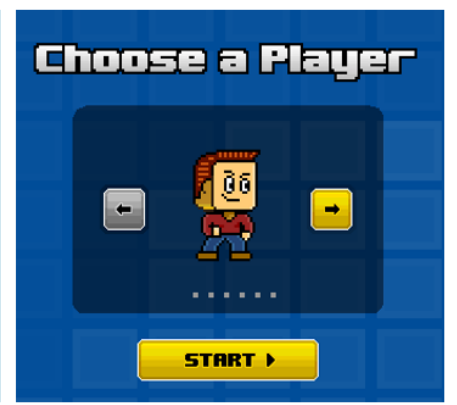

MENU DE ESCOLHA DO PERSONAGEM

Fonte: telas do jogo no Sploder, capturadas pelos autores.

O botão "start" conduz o jogador para um outro menu onde ele deverá escolher um avatar 5 . O Sploder oferece até nove opções de avatares (Figura 4), cada um deles com as mesmas habilidades e respondendo aos mesmos comandos no teclado. Essa é uma predefinição da própria plataforma de criação, não sendo possível diminuir ou aumentar o número de personagens nesta modalidade.

É importante, também, evidenciar que não há diferenças técnicas entre os avatares nos quesitos energia, resistência a danos, força, velocidade e poder, independentemente da escolha.

\footnotetext{
4 Disponível em: http://www.sploder.com/games/members/mestradoifrs/play/mundo-da-metodologia-2/.

5 Segundo Bell e Robbins-Bell (2008), o avatar é um personagem gráfico que possui agência (habilidade de realizar ações) e que é controlado por um agente humano em tempo real.
} 
Figura 4 - Avatares do jogo Mundo da Metodologia.

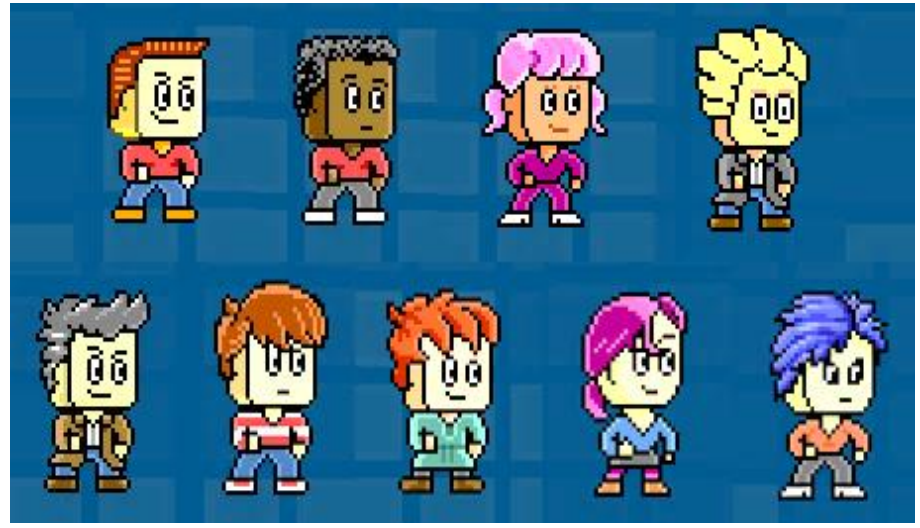

Fonte: telas do jogo no Sploder, capturadas pelos autores.

Como um meio de proporcionar uma leitura apropriada no que tange ao andamento e o desempenho dos jogadores na partida, já ao ingressar na primeira fase do Mundo da Metodologia, tem-se à disposição cinco indicadores, como conceitua Alves (2014) - localizados em posições padronizadas na tela. São eles: saúde, vidas, pontuação, magia e nível de energia (Figura 5).

Figura 5 - Layout dos indicadores na tela do jogo.

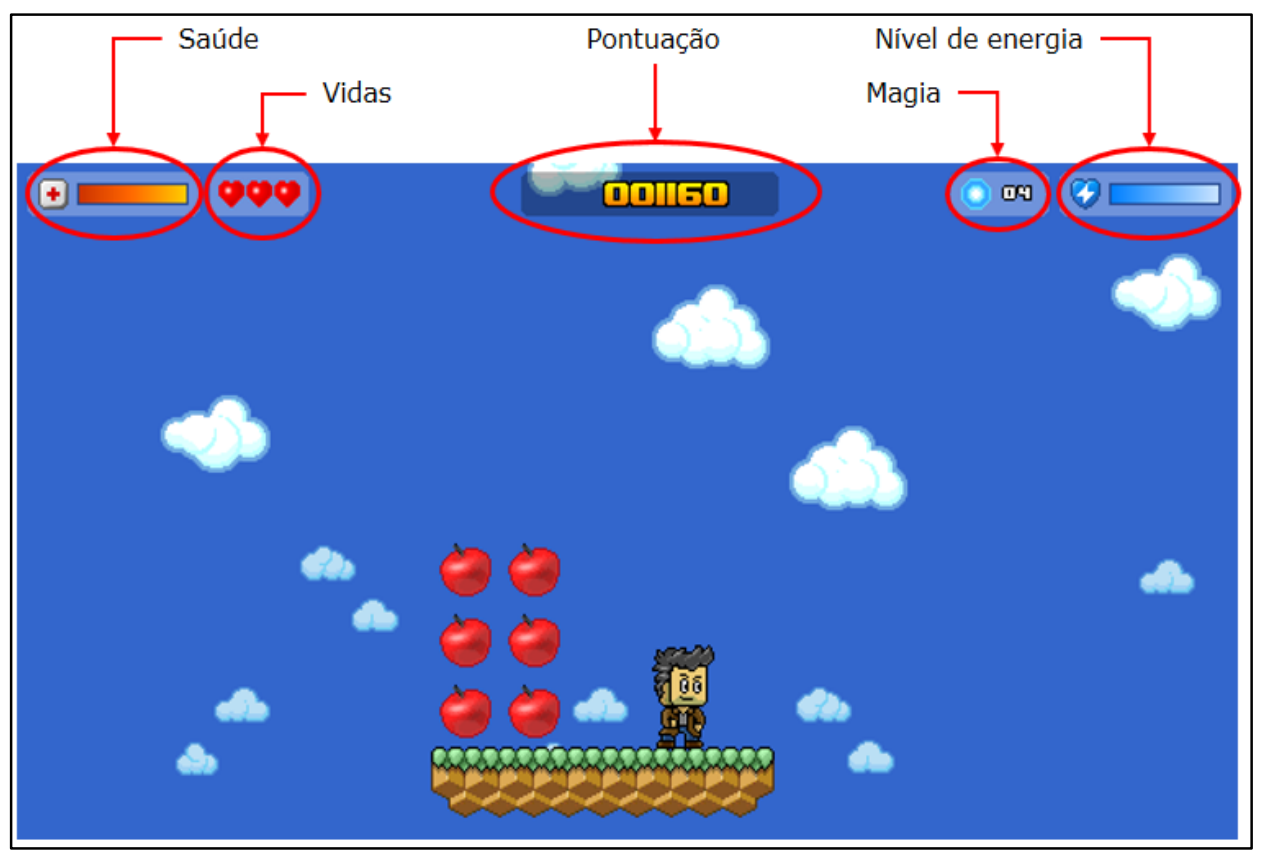

Fonte: telas do jogo no Sploder, capturadas pelos autores.

$\mathrm{O}$ indicador saúde refere-se à resistência física do protagonista. Representado por uma barra laranja, quanto mais danos o personagem sofrer ao longo de suas missões, mais essa barra se esvaziará. Ele está diretamente ligado a outro relevante indicador: vidas. Representadas por um coração, cada vida do protagonista representa uma tentativa de completar o jogo. Isso significa que os jogadores terão até três chances para finalizar o jogo, sem ter de recomeçá-lo. Contudo, ao se esgotar a barra de saúde do personagem, uma tentativa terá se esvaído. 
$\mathrm{O}$ indicador pontuação refere-se ao desempenho do protagonista ao longo do caminho. Na medida em que o personagem avança, coleciona moedas de ouro, resgata tesouros e derrota inimigos, este escore aumenta.

O personagem conta com um poder mágico para enfrentar seus desafios. De posse desse recurso, o protagonista pode congelar seus inimigos com apenas um disparo. E é sobre isso que se trata o indicador magia. Ele aponta o número de disparos que podem ser utilizados.

Além da resistência contra danos, é possível, também, avaliar o indicador que mede a disposição física do avatar ao longo da partida. Esse indicador, chamado nível de energia, é representado por uma barra azul e simboliza o fôlego do personagem para a realização de saltos, rasteiras e outros movimentos.

Alves (2014) sustenta que a aplicação de elementos básicos - como esses - fazem dos jogos atividades mais engajadoras, transportando os participantes para uma experiência envolvente e imersiva. Boler e Kapp (2018), todavia, citam que o estabelecimento da meta também é essencial, em virtude de que é através dela é que se alcança um estado de vitória dentro do game, podendo ela ser uma conquista do participante ou o encerramento do próprio jogo. Em games na modalidade plataforma, a meta se dá através do cumprimento de fases e/ou da promoção do personagem à excelência, fazendo-o atingir um nível máximo, conforme ele se desenvolve.

Embora o Mundo da Metodologia tenha sido pensado para ser um jogo voltado ao ensinoaprendizagem, ao longo de suas duas fases foram acrescentados diversos objetos que, além de contribuírem para tornar o jogo mais divertido, vão ao encontro do que é sustentando pelo autor, servindo, inclusive, como formas de recompensa. Entre eles estão: diamantes que ajudam a repor as energias do protagonista; frutas que restauram a saúde do personagem; e tesouros e moedas de ouro que aumentam a pontuação dos jogadores (Quadro 1). 
Quadro 1 - Recompensas encontradas ao longo do jogo.

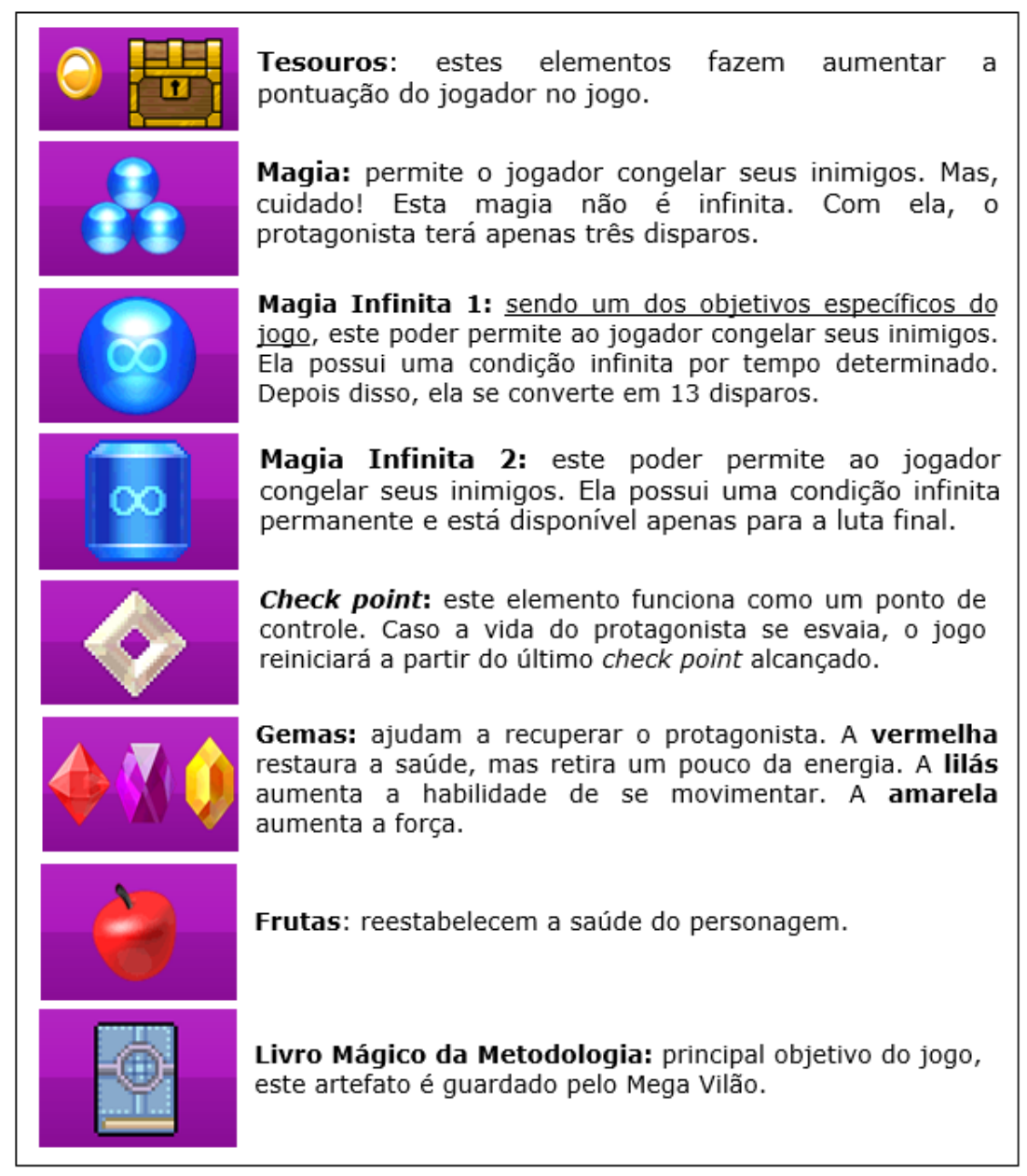

Fonte: os autores.

Além desses, o ambiente conta com outros componentes de interação que ajudam na narrativa e conduzem o jogo a uma dinâmica mais coerente com a proposta de um jogo de plataforma (Quadro 2). Estão entre eles: os antagonistas, portais de teleporte, interruptores para acionamento de elementos móveis dos cenários e os non-player characters (NPCs ou personagens não controlados pelo jogador, em tradução livre).

Conforme Durazzo e Badia (2011), o NPC é um personagem figurante que possui a tarefa de interagir com o jogador, apresentando elementos da narrativa criada pelo narrador. Chandler (2012) explica que o jogador pode conversar com o NPC, que pode ser representado por um guardião, por exemplo, e receber uma missão. Na sequência, o jogador tem a opção de realizar essa missão sozinho ou, como ocorre em alguns jogos, através da formação de grupos com outros jogadores ativos ${ }^{6}$ para executá-la.

\footnotetext{
6 É oportuno destacar que o Mundo da Metodologia funciona na modalidade single player, o que significa que ele opera no
} formato de jogador único, não sendo possível a formação de grupos ativos. 
Quadro 2 - Componentes de interação do jogo.

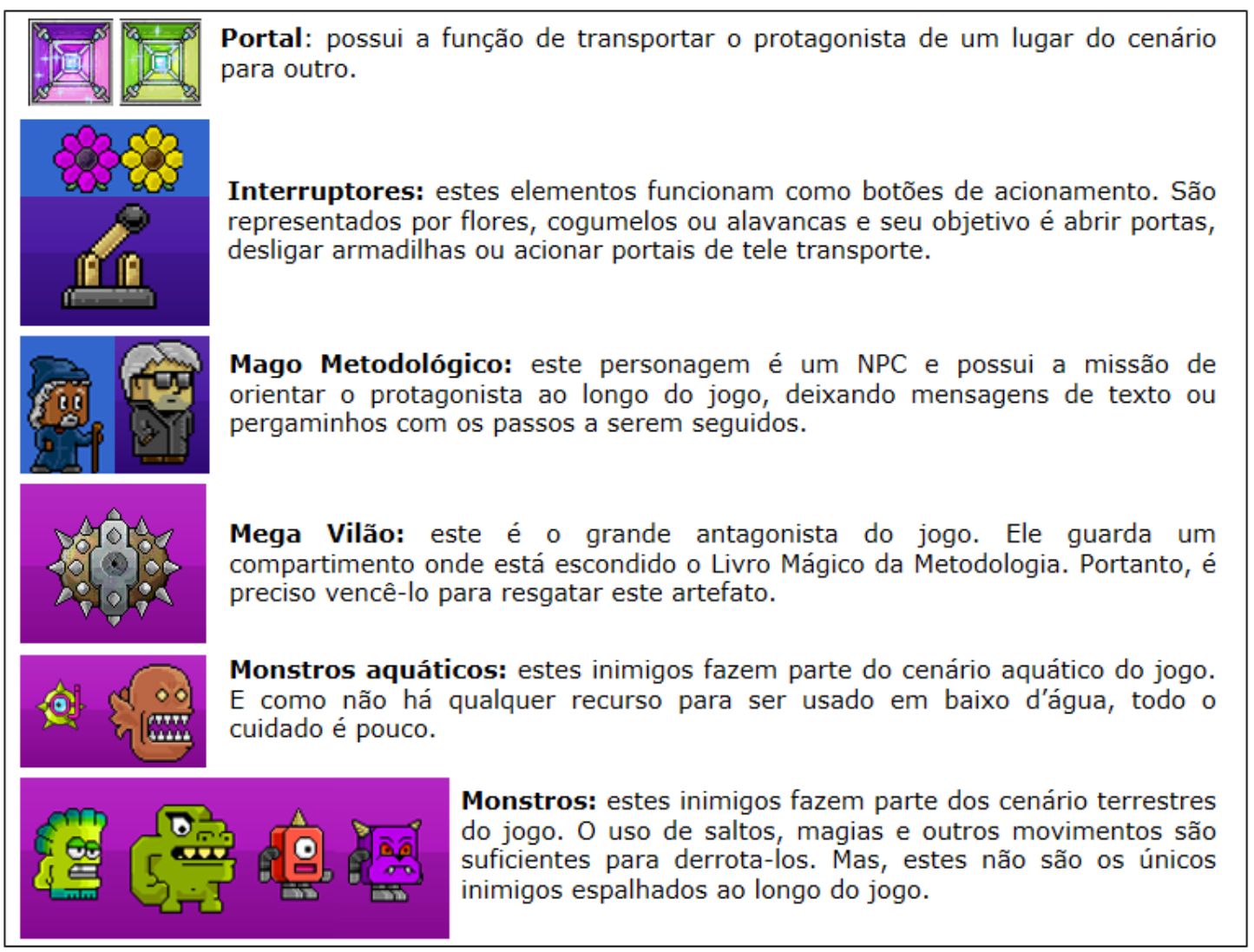

Fonte: os autores.

No Mundo da Metodologia, o NPC - aqui representado pelo Mago Metodológico - tem a função de apresentar o jogo, passar orientações acerca das tarefas a serem executadas pelo jogador, objetivos a serem realizados e objetos a serem colecionados ao longo da jornada (Figura 6).

Figura 6 - Contato do jogador com o NPC.

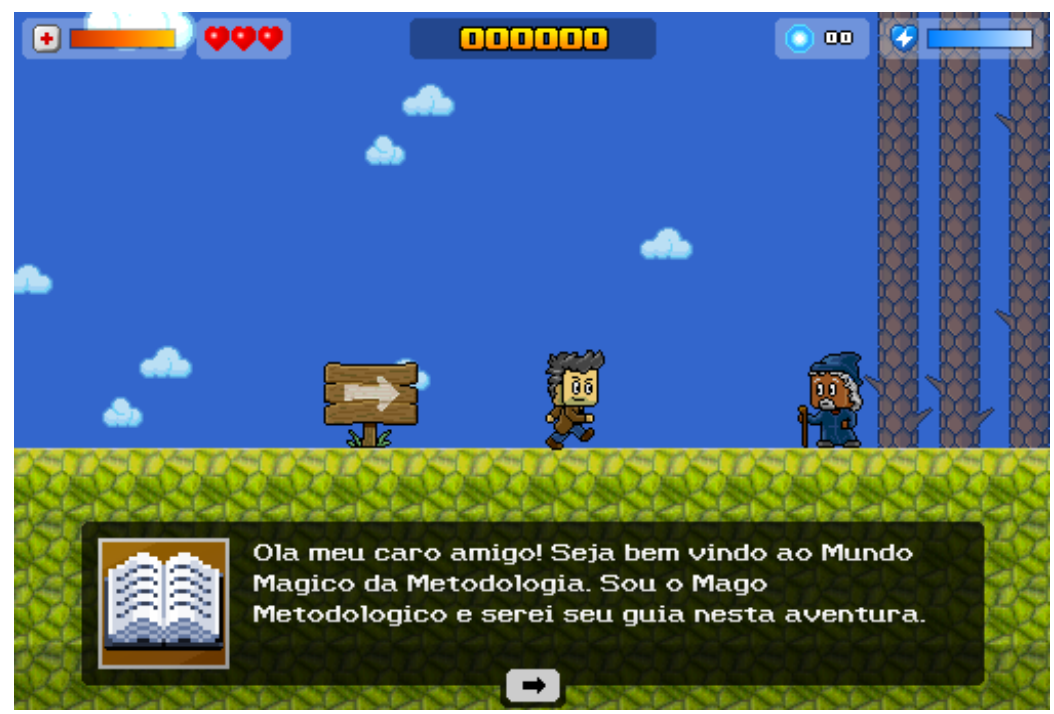

Fonte: telas do jogo no Sploder, capturadas pelos autores. 
Na visão de Bonatti (2014), o universo dos jogos eletrônicos é muito grande e está em plena expansão, ainda que não seja formado unicamente por pessoas que se encaixem no estereótipo de um jogador de videogame habitual. Grande parte desse crescimento deve-se aos chamados jogadores casuais; aqueles que preferem jogos simples, rápidos e que podem ser acessados de qualquer local, independentemente de ser pelo dispositivo móvel ou pelo browser de navegação. Pensando nisso, entendeu-se que a modalidade plataforma era uma opção adequada para fazer do Mundo da Metodologia um jogo curto, inteligível e acessível. Pois, mesmo que nem todos os universitários se enquadrem na classe de jogadores habituais, o grau de simplicidade dessa categoria de jogos não representaria dificuldades para jogadores iniciantes e/ou casuais, aumentando as chances de atingir ambos os perfis apontados pelo autor.

Apesar de Mattar (2010) fazer a leitura de que os jogos eletrônicos, como nenhuma outra mídia, geram envolvimento por atrair pessoas estimuladas pelo entretenimento e interatividade, Busarello (2016) acredita que o sucesso dos games vai além do fator diversão. Para ele, o envolvimento das experiências do indivíduo, a partir das práticas frente às regras de um novo mundo ficcional, é essencial para gerar estratégias motivacionais e engajadoras, facilitando o processo de construção de significado.

Vale esclarecer que esses aspectos percebidos por Busarello (2016) foram relevantes para complementar o Mundo da Metodologia, em especial, sob dois enfoques. O primeiro está vinculado ao aproveitamento das experiências dos jogadores habituais com jogos similares, ainda que oriundos de outros sistemas, o que amplia as possibilidades de obtenção de feedbacks construtivos em relação ao jogo, dado o senso crítico destes sobre o assunto. O segundo está ligado à criação de um envolvimento emocional com os jogadores casuais, posto que a inteligibilidade das linhas de comando do avatar - e que serão apresentadas na subseção seguinte - podem oferecer facilidades para os mais iniciantes, contribuindo para a construção deste elo.

\subsection{Comandos do avatar}

Seguindo a mesma linha de outros jogos da categoria plataforma, o Mundo da Metodologia oferece linhas de comando bastante simples para movimentar o avatar. Para acessá-las, basta que o jogador simplesmente ingresse no jogo. Automaticamente, um pequeno quadro de instruções surgirá no canto esquerdo da tela, detalhando cada movimento do protagonista e o comando do teclado correspondente (Figura 7).

Figura 7 - Quadro de instruções das linhas de controle do avatar.

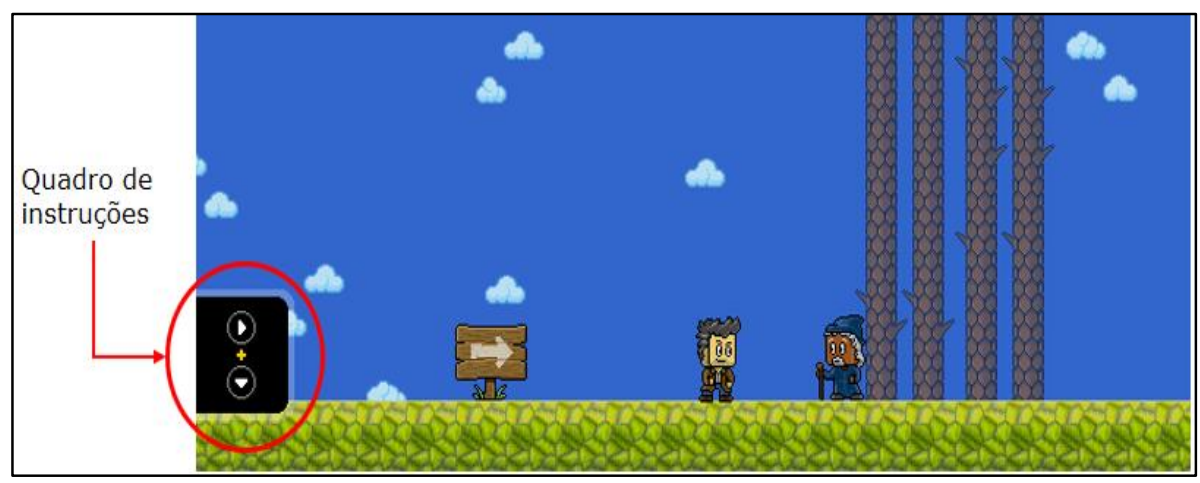

Fonte: telas do jogo no Sploder, capturadas pelos autores.

No Quadro 3, são apresentadas as linhas de controles que o jogador encontrará no quadro de instruções. Ao total, o jogo conta com nove comandos, considerando os movimentos para frente e para trás, saltos, rasteiras e magia. Segundo Togneri e Lorenzoni (2005), a utilização de comandos simples, ativados por botões de controle, pode minimizar a complexidade de interação 
entre o jogador humano e os componentes virtuais do jogo, sejam eles oponentes ou aliados (apoio).

Quadro 3 - Linhas de controle do avatar.

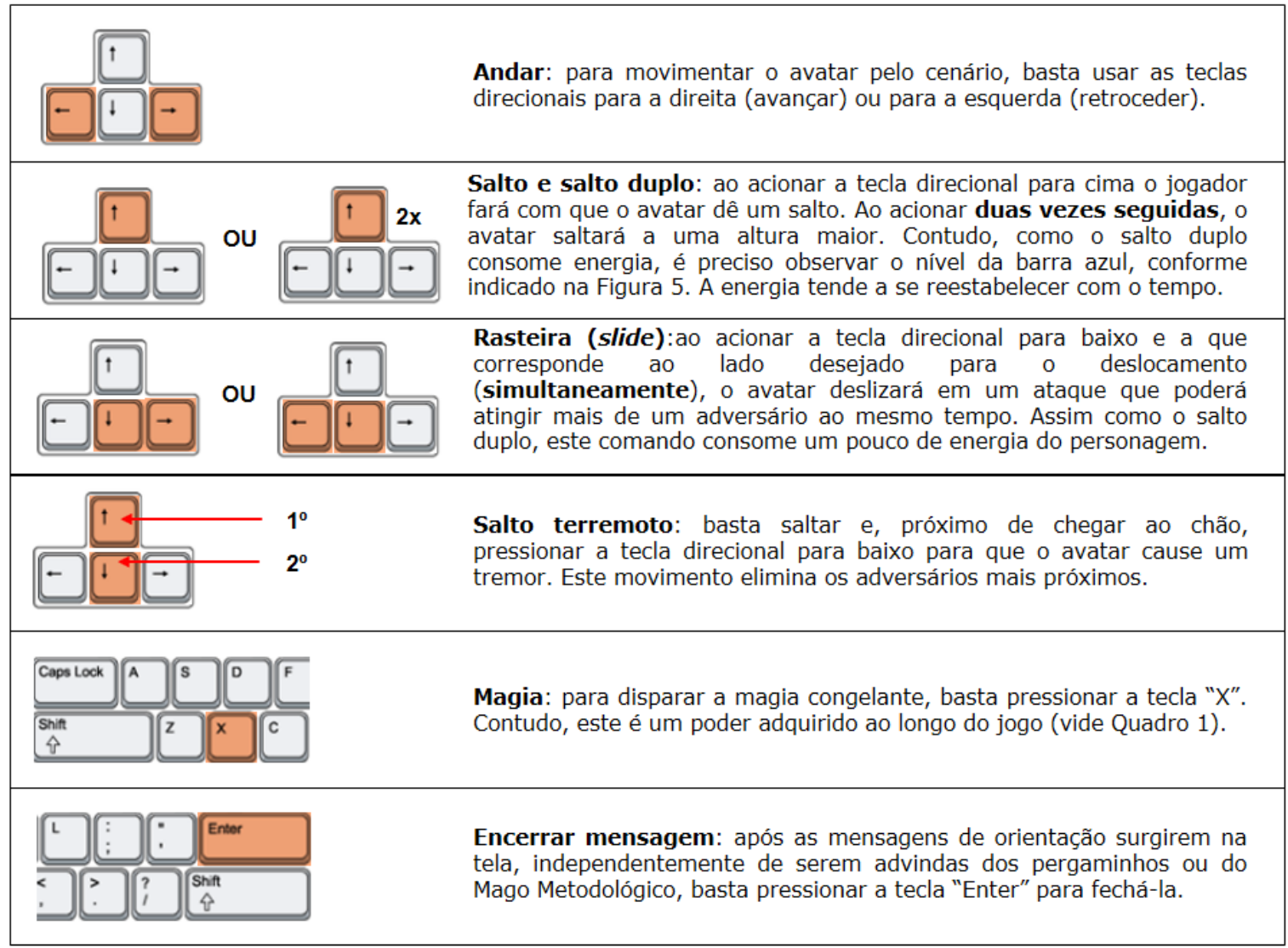

Fonte: os autores.

O uso de linhas de controle é pertinente para proporcionar um certo grau de autonomia aos jogadores, o que, na visão de Burke (2015), é fundamental para tornar os games eficientes, afinal oportuniza aos competidores descoberta e aprendizado sobre os diferentes caminhos para alcançar um objetivo proposto. Para Kelly (2017), esse livre-arbítrio é primordial para gerar um equilíbrio entre a narrativa do jogo e a interação orientada, criando, assim, a percepção de uma excelente jogabilidade. Nas palavras do autor, o conceito de jogabilidade está vinculado à agradável sensação de fazer parte de algo grande que está avançando (a narrativa do jogo), ao mesmo tempo em que o jogador tem o controle de suas próprias escolhas.

\section{Ligação com conceitos introdutórios de Metodologia da Pesquisa}

Conforme observa Carramenha (2012), tão importante quanto a clara identificação do problema é a definição dos objetivos da pesquisa, visto que eles representam a declaração do que se pretende alcançar com o projeto. Para Tozoni-Reis (2010), a definição dos objetivos é uma das etapas cruciais de um trabalho científico, posto que, é a partir deles, que se pode delinear o desdobramento da pesquisa.

O objetivo de um estudo científico, de acordo com Prodanov e Freitas (2013), está diretamente vinculado à própria significância da tese proposta pelo pesquisador, devendo ele estar atento quanto à intensão de propor a pesquisa; ou seja, sintetizar o que se deseja alcançar com ela. Esses objetivos, segundo Santos, Molina e Dias (2007), se subdividem em objetivo geral 
- aquele que traz a síntese do que se deseja alcançar com o projeto - e objetivos específicos aqueles os quais devem fornecer uma rigorosa descrição das ações para que o objetivo geral seja alcançado -, estando desdobrados em uma ordem linear ao desenvolvimento do estudo.

Procurando um alto grau de efetividade de aplicação, o Mundo da Metodologia foi estruturado seguindo duas premissas de Boler e Kapp (2018), a começar pela de que, quando se está criando um jogo de aprendizagem, deve-se começar com um objetivo instrucional específico para que o game não se torne complicado demais para um arranjo temporal idealizado. Tentar ensinar tudo num só jogo é um equívoco comum entre os designers. Assim, os autores aconselham que se foque num processo em especial com regras simples, expandindo-o somente se necessário.

A segunda premissa determina que todo game de aprendizagem deve possuir uma meta do jogo e um objetivo instrucional ${ }^{7}$. Partindo da recomendação Boler e Kapp (2018), de que um jogo precisa ser criado de forma que o estado de vitória esteja relacionado com a aquisição do conhecimento, estipulou-se uma relação direta entre a meta do jogo e os objetivos instrucionais, estando cada uma das três metas correspondendo a um objetivo específico que, se cumpridas, permitirão ao competidor atingir o objetivo central do jogo - como as premissas teóricas exploradas por ele presumem (Quadro 4).

Quadro 4 - Relação entre as metas do jogo e os objetivos instrucionais.

\begin{tabular}{|c|c|}
\hline Metas do Jogo & Objetivos Instrucionais \\
\hline $\begin{array}{l}\text { Objetivo central do jogo: resgatar o Livro Mágico da } \\
\text { Metodologia }\end{array}$ & $\begin{array}{l}\text { Relação di } \\
\text { geral. }\end{array}$ \\
\hline $\begin{array}{l}\text { Meta 1: derrotar os inimigos na floresta. } \\
\text { Meta 2: enfrentar o mar turbulento e encontrar a magia infinita. } \\
\text { Meta 3: vencer o Mega Vilão. }\end{array}$ & $\begin{array}{l}\text { Relação direta com o conceito e } \\
\text { desdobramento linear dos objetivos } \\
\text { específicos. }\end{array}$ \\
\hline
\end{tabular}

Fonte: os autores.

Para garantir a proximidade com os referidos fundamentos da Metodologia da Pesquisa, foram estabelecidos dois dispositivos: (1) o NPC que orienta o jogador sobre a meta a cumprir faz a equivalência desta com os objetivos instrucionais e direciona o competidor para o desafio seguinte após o anterior estar finalizado; e (2) mecanismos que conduzem o jogador a ter que cumprir inteiramente um objetivo específico (meta) para que ele possa avançar ao próximo, impedindo que ele transpasse etapas sem que estejam devidamente completadas.

\section{Materiais e Métodos}

O presente artigo envolve uma pesquisa quase-experimental, de caráter exploratóriodescritivo, com pesquisa mista; e levantamento de dados através de observação direta, pesquisa documental, entrevistas e questionário. Este estudo, com as técnicas e características descritas, foi realizado nas instituições que aqui serão chamadas de Universidade 1 e Universidade 2, entidades particulares de ensino superior localizadas na cidade de Caxias do Sul, RS, e teve como objetivo central verificar a efetividade do Mundo da Metodologia como apoio aos alunos para compreensão e aplicação prática dos princípios que fundamentam a composição dos objetivos dentro de uma pesquisa científica.

Para tal averiguação, o game foi introduzido em uma atividade prática não avaliativa prevista no plano de aula das disciplinas Metodologia da Pesquisa e Empreendedorismo, matérias ofertadas pelas instituições objeto do estudo, às quais contemplam a elaboração de trabalhos científicos. A definição quanto aos participantes deu-se através de um convite aberto direcionado

\footnotetext{
7 Boler e Kapp (2018) conceituam a meta do jogo como o que o jogador faz para obter o estado de vitória, enquanto o objetivo instrucional é tudo aquilo que o jogador deverá aprender com o jogo. Os autores esclarecem que identificar o objetivo instrucional é tão importante quanto a meta do jogo para que se tenha uma perspectiva geral sobre ele.
} 
pela combinação de dois critérios não probabilísticos: (1) os acadêmicos tinham que estar matriculados nas instituições objeto do estudo e (2) inscritos nas disciplinas (Quadro 5). Visto que não se tratava de uma atividade obrigatória, formou-se uma amostra de 17 alunos; porém, eles poderiam desistir de sua participação a qualquer momento, sem penalidades.

Quadro 5 - Distribuição da amostra.

\begin{tabular}{|c|c|c|c|c|c|c|}
\hline IES & $\begin{array}{c}\text { Turma/ } \\
\text { semestre }\end{array}$ & Disciplina & $\begin{array}{c}\text { Tamanho } \\
\text { da turma }\end{array}$ & $\begin{array}{c}\text { Participantes } \\
\text { não formandos }\end{array}$ & $\begin{array}{c}\text { Participantes } \\
\text { formandos }\end{array}$ & Total \\
\hline Universidade 1 & $2016 / 1$ & Metodologia da Pesquisa & 10 & - & 6 & 6 \\
\hline Universidade 2 & $2017 / 1$ & Empreendedorismo & 40 & 3 & 8 & 11 \\
\hline Total de acadêmicos participantes do experimento & & & 17 \\
\hline
\end{tabular}

Fonte: os autores.

Com vistas a maximizar seu aproveitamento, o jogo foi empregado em um espaço híbrido, cujo caráter de hibridismo deu-se através do uso sequencial de três plataformas, começando pelo próprio game. Em um primeiro momento, após serem instruídos quanto aos objetivos da atividade e aos elementos que fazem parte do universo do jogo (vide seção 4), os acadêmicos foram conduzidos ao laboratório de informática onde, individualmente, jogaram o Mundo da Metodologia, tomando nota de suas percepções sobre os conceitos explorados.

Em um segundo momento, aferiu-se o desempenho dos participantes, utilizando um instrumento avaliativo, autocorrigível ${ }^{8}$, postado no ambiente virtual de aprendizagem (AVA) de cada universidade. Composto por duas questões objetivas de múltipla escolha, o aluno precisava relacionar os princípios teóricos adquiridos no game com os conceitos teóricos de Metodologia da Pesquisa explorados por ele. Na questão 1, os acadêmicos precisaram relacionar os conceitos de objetivo geral e objetivos específicos de acordo com as bases do jogo, sendo que a alternativa " $d$ " é a única que apresenta a sequência correta (Figura 8).

Figura 8 - Primeira pergunta do questionário avaliativo.

Questão 1. Divididos em gerais e específicos, os objetivos de uma pesquisa
constituem a finalidade de uma pesquisa cientifica. Com base no jogo Mundo da
Metodologia, relacione os itens a seguir.
I. Objetivo geral
II. Objetivo específico 1
III. Objetivo específico 2
IV. Objetivo específico 3
1.( ) Derrotar os inimigos na floresta.
2.( ) Vencer o Mega Vilão.
3.( ) Resgatar o Livro Mágico do Mundo da Metodologia.
4.( ) Enfrentar o mar turbulento e encontrar a magia infinita.
A alternativa que apresenta a sequência correta é:
a) ( ) I, II, III e IV.
b) ( ) II, III, IV e I.
c) ( ) IV, I, III e II.
d) ( ) II, IV, I e III.
e) ( ) III, I, IV e II.
Fonte: os autores.

\footnotetext{
8 O questionário estava parametrizado para que fosse respondido em apenas uma tentativa, bem como estava configurado
} para autocorreção somente após o participante ter respondido as duas questões. 
Na questão 2, os alunos precisaram identificar as asserções verdadeiras e falsas, de acordo com o entendimento deles sobre os conceitos adquiridos através do jogo. A alternativa "b" é a única que apresenta a sequência correta (Figura 9).

Figura 9 - Segunda pergunta do questionário avaliativo.

Questão 2. Considerando os conceitos de objetivo geral e de objetivos específicos,
analise as sentenças abaixo:
I. Objetivo geral de um trabalho científico traz a síntese do que o pesquisador deseja
alcançar com o projeto.
II. Os objetivos específicos são idênticos ao objetivo geral, podendo, assim, a
pesquisa possuir mais de uma sintese do que o pesquisador deseja alcançar.
III. Os objetivos específicos descrevem, de forma linear, os desdobramentos das
ações para que o objetivo geral seja atingido.
IV. A sequência dos objetivos específicos não precisa ser rigorosamente em
sequência, desde que mantenham sua ligação com o objetivo geral, visto que este
representa a síntese do trabalho científico.
A alternativa que apresenta a sequência correta se asserções verdadeiras e falsas é:
a) ( ) F, V, F, V.
b) ( ) V, F, V, F.
c) ( ) V, V, F, F.
d) ( ) V, F, F, F.
e) ( ) F, F, V, F.

Fonte: os autores.

No momento final, um dos pesquisadores aferiu novamente o desempenho dos participantes; porém, desta vez, através da composição escrita dos objetivos que constituem a finalidade de uma pesquisa. Servindo-se da grafia como plataforma física, os alunos tiveram que delinear um objetivo geral e, ao menos, três específicos para projetos cujos temas eram de livre escolha.

Após o término da atividade, os estudantes foram convidados a participar do processo de validação, ficando livres para emitirem suas percepções sobre o game. Por meio da ferramenta Formulários do Google, elaborou-se um questionário composto por seis questões (vide subseção 7.2) e, tal como ocorreu na atividade proposta para o presente estudo, a participação dos acadêmicos no processo foi voluntária e anônima, podendo eles desistir a qualquer momento, sem penalidades.

\subsection{Perfil dos participantes}

De forma que se pudesse ter um entendimento mais amplo sobre o perfil dos participantes, os alunos foram previamente entrevistados, como mostra a Figura 10, apontando que, dos 17 participantes, $13(76,47 \%)$ são oriundos dos cursos de gestão, enquanto quatro $(23,53 \%)$ estão matriculados em cursos de engenharia. Ao serem questionados se estavam cursando a disciplina de Metodologia da Pesquisa, 14 deles (82,35\%) responderam que recém haviam se matriculado, sendo que: seis $(42,86 \%)$ afirmaram terem percepções iniciais de que o conteúdo era fácil e não sentiam dificuldades; cinco $(35,71 \%)$ ponderaram dificuldades em seus primeiros contatos com a matéria; e os três restantes $(21,43 \%)$ entenderam que a disciplina é pouco objetiva, tornando os conceitos iniciais muito complexos. Chama a atenção, porém, que $100 \%$ dos acadêmicos responderam não ter conhecimento sobre os princípios teóricos que envolvem os objetivos de uma pesquisa e tão pouco como é dada a sua elaboração. 
Figura 10 - Levantamento quanto ao perfil dos participantes do experimento.

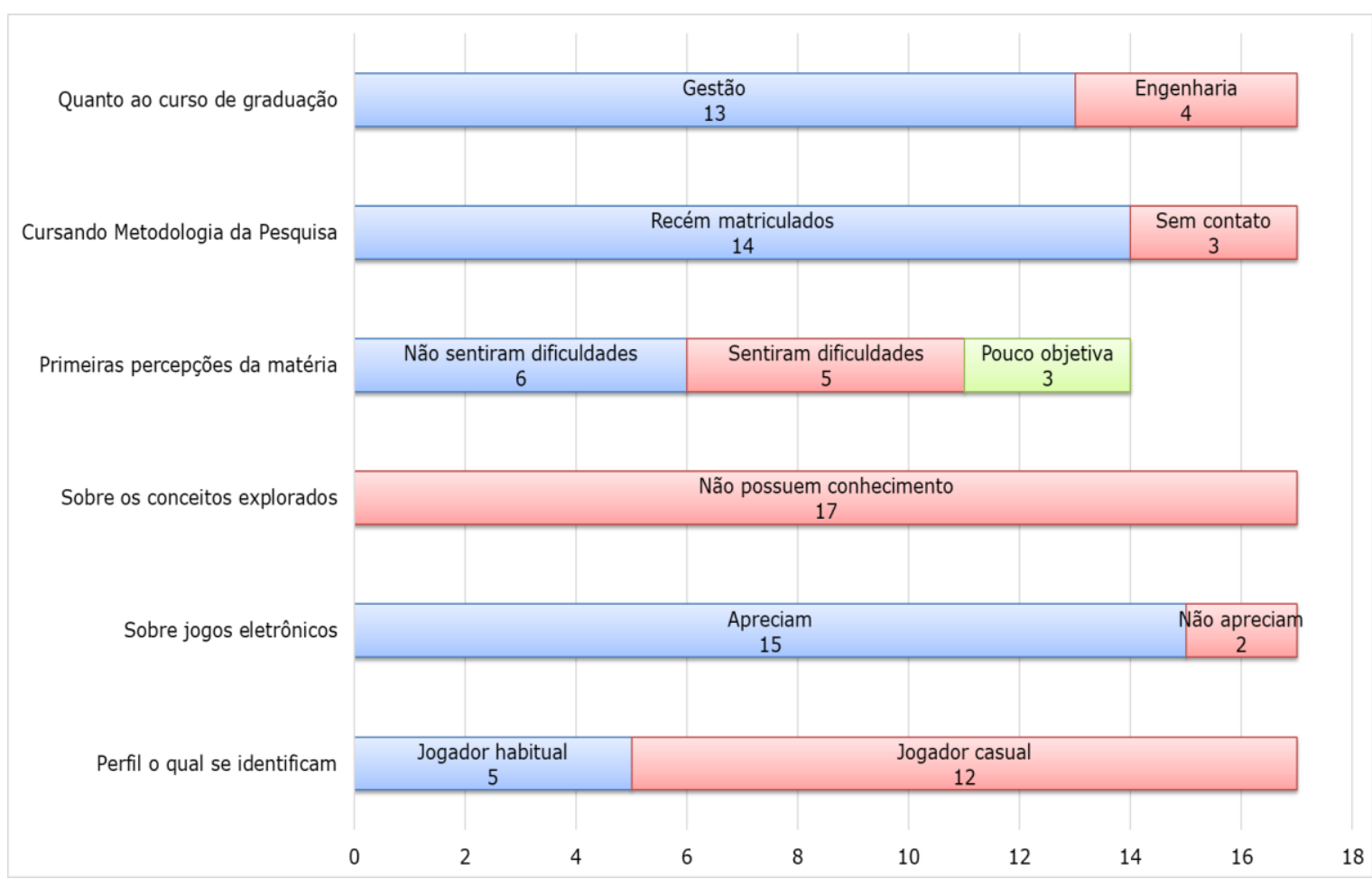

Fonte: os autores.

Ainda que 15 acadêmicos $(88,24 \%)$ tenham demonstrado afinidade com jogos eletrônicos e outros dois $(11,76 \%)$ tenham manifestado não apreciá-los, todos os participantes se dispuseram a responder o último questionamento referente ao perfil de jogador com o qual cada um mais se identificava. Nesse caso, cinco participantes $(29,41 \%)$ se classificaram como jogadores habituais, enquanto os demais 12 alunos (70,59\%) como jogadores casuais.

\section{Análise dos resultados}

Nesta seção, apresentam-se os resultados apurados neste estudo, dividindo-os nas seguintes subseções: os indicadores de desempenho advindos do experimento prático realizado em sala de aula e a validação do Mundo da Metodologia junto aos participantes.

\subsection{Análise do desempenho dos participantes}

Após a etapa introdutória, os participantes foram submetidos a uma sessão prática do Mundo da Metodologia. Não havendo certeza sobre o grau de adaptação dos estudantes acerca dos cenários, controles do teclado ou outros elementos que compõem a dinâmica de jogo, ficou préestabelecido que a sessão teria duração máxima de 20 minutos.

Finalizado o tempo de interação com o jogo, os acadêmicos voltaram-se para os AVAs de suas respectivas instituições e acessaram o primeiro questionário avaliativo. Mesmo não tendo sido programado um temporizador automático para o término do referido instrumento, ficou estipulado que a tarefa em questão teria duração máxima de 10 minutos. Nesta etapa, apurouse que os acadêmicos atingiram $100 \%$ de acerto em ambas as questões - isso sem que 0 professor fosse acionado para o esclarecimento de qualquer tipo de dúvida em relação aos conceitos ou ao enunciado das questões.

Ainda que o tempo empregado para a realização da tarefa não estivesse entre os indicadores inicialmente considerados para aferir o desempenho dos participantes, é importante destacar que 
o período limite previamente estipulado para a conclusão da atividade não precisou ser utilizado em sua totalidade, posto que o aluno mais rápido terminou a atividade em 2 minutos e o último questionário foi encerrado 4 minutos após o início.

No que tange ao segundo instrumento avaliativo, observou-se que todos os participantes apresentaram propostas assertivas, tendo em vista os conceitos que envolvem a elaboração dos objetivos de uma pesquisa. É preciso evidenciar, entretanto, que mesmo havendo um caso $(5,88 \%)$ onde a não linearidade na sequência dos objetivos específicos tenha sido constatada, estes não se encontravam em desacordo com as bases teóricas que fundamentam a sua concepção, uma vez que eles ainda representavam os desdobramentos do objetivo geral.

\subsection{Validação do jogo}

Ao término do experimento, os 17 estudantes foram convidados a proceder com a validação do jogo. Através do questionário composto por cinco perguntas objetivas e uma descritiva, buscou-se identificar o nível de aprovação dos jogadores quanto à aplicação do Mundo da Metodologia como um suporte no processo de aprendizagem. O que se constatou ao fechamento desta avaliação é que $100 \%$ dos participantes aderiram à pesquisa de feedback.

Ao responder à primeira questão sobre se o jogo deixa claro quais são os seus objetivos e quais tarefas devem ser cumpridas, constatou-se que há um resultado positivo em $100 \%$ das respostas (Figura 11a). Quanto ao jogo deixar claro os conceitos de objetivo geral e objetivos específicos, nota-se, mais uma vez, um resultado positivo em $100 \%$ das respostas, visto que $71 \%$ dos jogadores concordaram e $29 \%$ concordaram totalmente (Figura 11b).

Figura 11 - Avaliação sobre se o jogo deixa claro seus objetivos e tarefas a serem cumpridas.

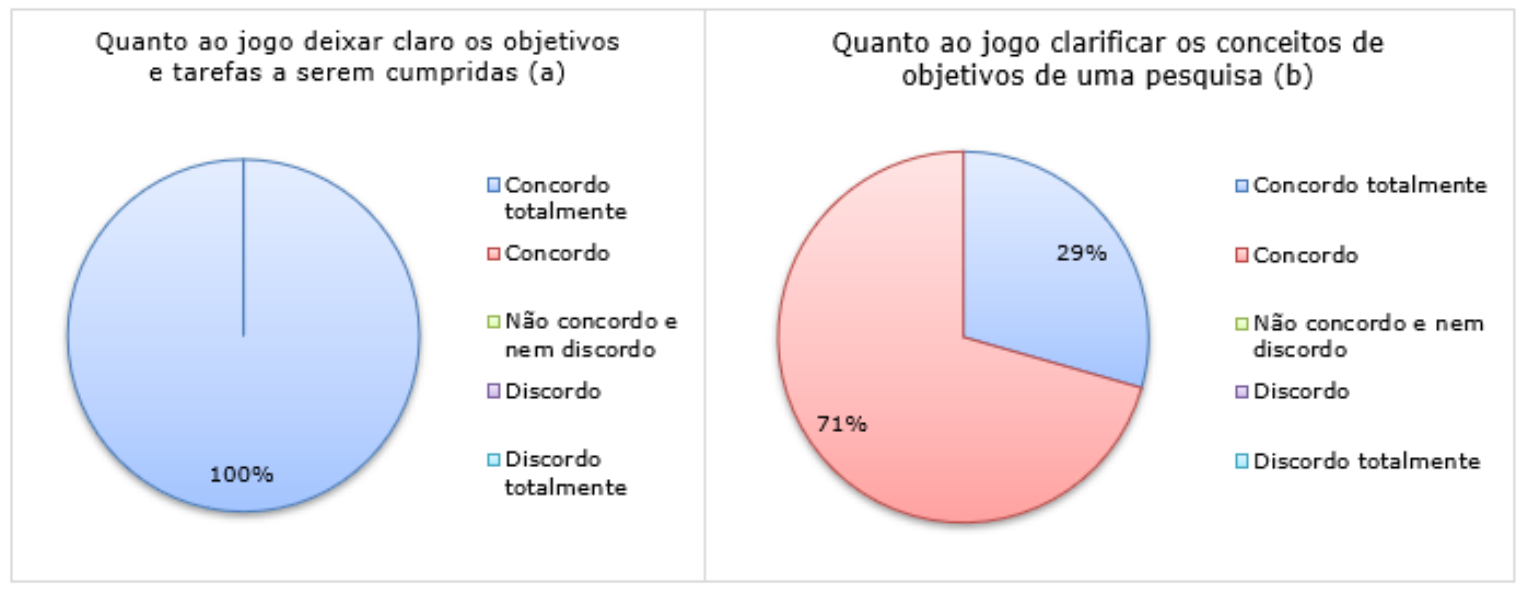

Fonte: os autores.

Sobre as dificuldades encontradas ao longo da partida, $47 \%$ dos jogadores afirmaram não ter enfrentado qualquer dificuldade; $41 \%$ enfrentaram alguma dificuldade inicial quanto à adaptação aos comandos do teclado; e 12\% sentiram dificuldades iniciais quanto ao nível de jogabilidade (Figura 12). Vale ressaltar que, segundo esses dados - e que corroboram com o que foi percebido através de observação direta -, todos os percalços vivenciados pelos participantes foram nos primeiros minutos de contato com o Mundo da Metodologia. Nos instantes seguintes, os pontos aqui levantados foram gradualmente se minimizando, sem o suporte do professor. 
Figura 12 - Avaliação quanto às dificuldades encontradas ao longo da partida.

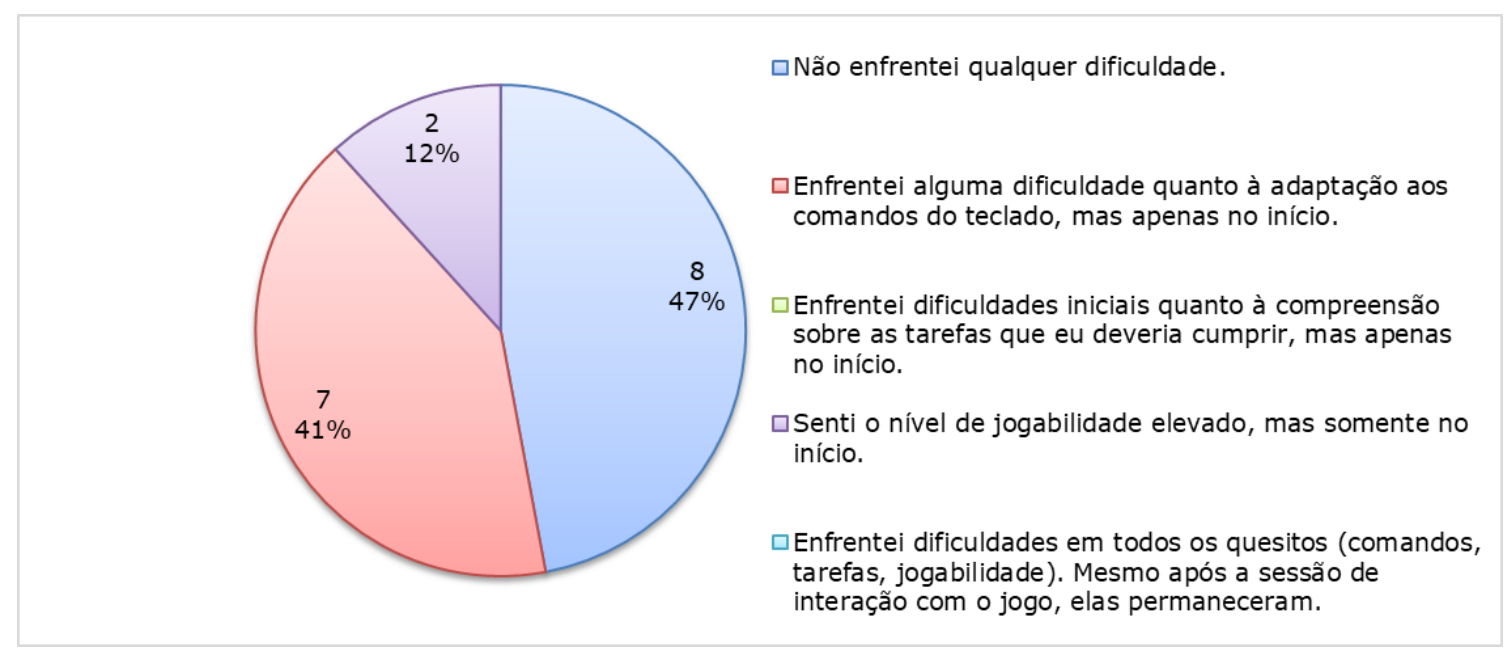

Fonte: os autores.

No que tange à contextualização dos princípios teóricos explorados pelo Mundo da Metodologia, $100 \%$ dos jogadores apontaram que o jogo faz tal abordagem de forma divertida e envolvente, facilitando, assim, o processo de aprendizagem dentro da disciplina (Figura 13).

Figura 13 - Avaliação sobre a contextualização dos princípios teóricos explorados pelo jogo.

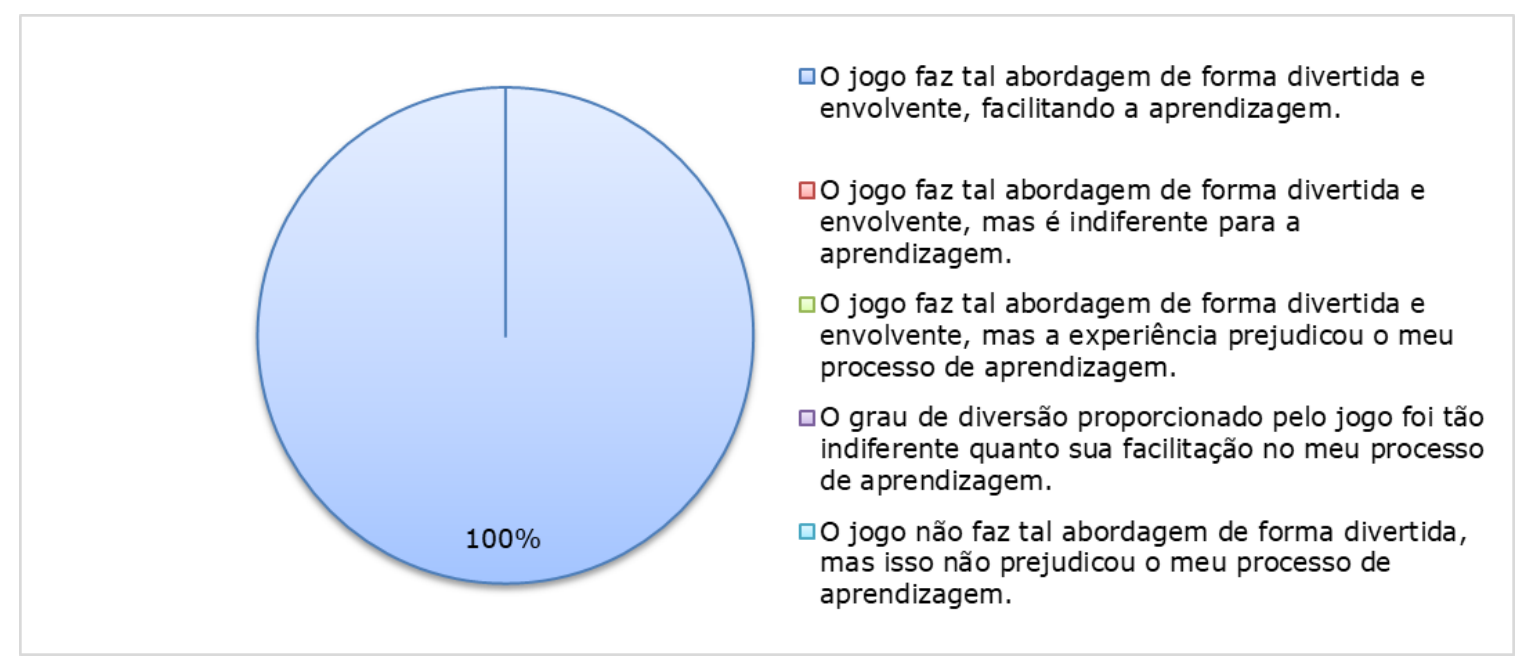

Fonte: os autores.

Na sequência, foi solicitado aos acadêmicos que atribuíssem uma nota de 0,0 (zero) a 10,0, sendo que 0,0 (zero) corresponde ao grau de "muito insatisfeito" e 10,0 ao de "muito satisfeito". A Figura 14 mostra a avaliação dos estudantes na exata sequência em que responderam à pesquisa. Conforme o gráfico, nove acadêmicos avaliaram o jogo com nota 10,0; seis usuários com nota 9,0; e dois com nota 8,0. Considerando o total de participantes, a avaliação média do Mundo da Metodologia ficou em 9,4. 
Figura 14 - Avaliação individual dos participantes.

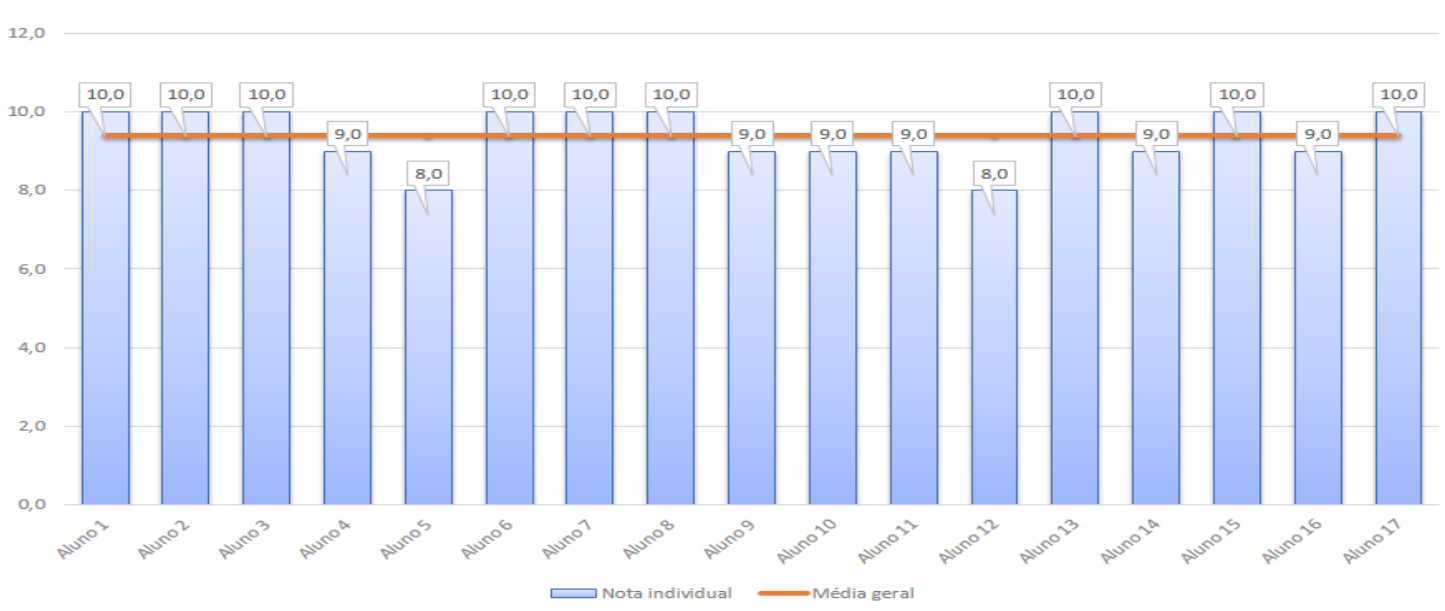

Fonte: os autores.

No espaço aberto para apontamentos qualitativos, localizado no final do questionário de validação, os acadêmicos puderam prestar suas contribuições ao projeto, seja justificando as notas atribuídas ao jogo ou na forma de críticas e propostas de melhoria (Quadro 6). Posto que a participação no feedback era opcional, notou-se um nível de retorno muito positivo dos estudantes, uma vez que 15 deles $(88,24 \%)$ responderam à questão.

Quadro 6 - Contribuições qualitativas dos participantes.

\begin{tabular}{|c|c|}
\hline Participante & Apontamentos \\
\hline Aluno 1 & Muito bom, mas poderia ter uma fase de treinos. \\
\hline Aluno 2 & $\begin{array}{l}\text { Muito bom, mas um manual ou uma fase de trenos ajudaria a melhorar a compreensão } \\
\text { dos comandos. }\end{array}$ \\
\hline Aluno 3 & Os comandos foram um pouco difíceis de se acostumar no início, mas foi possível jogar. \\
\hline Aluno 4 & $\begin{array}{l}\text { A cada objetivo específico, poderia ter uma mensagem informando que ele foi } \\
\text { cumprido. Quem sabe, um indicador percentual poderia referir a quantidade de } \\
\text { objetivos específicos cumpridos, dando uma noção melhor de onde o usuário está no } \\
\text { jogo. }\end{array}$ \\
\hline Aluno 5 & $\begin{array}{l}\text { O jogo cumpre com o que é prometido, além de ser muito divertido. Cheio de desafios } \\
\text { e de fácil compreensão. }\end{array}$ \\
\hline Aluno 6 & $\begin{array}{l}\text { No princípio, o jogo parecia difícil. Após eu me acostumar com os comandos, foi fácil. } \\
\text { Não me considero um grande apreciador de jogos eletrônicos, mas me diverti. }\end{array}$ \\
\hline Aluno 7 & $\begin{array}{l}\text { Consegui aprender com o jogo o que eu demoraria três aulas para compreender. } \\
\text { Normalmente, Metodologia da Pesquisa é uma coisa chata, mas assim eu aprendi me } \\
\text { divertindo. }\end{array}$ \\
\hline Aluno 8 & $\begin{array}{l}\text { O jogo cumpre com seu propósito de forma divertida. Cheguei a sentir uma nostalgia } \\
\text { da simplicidade e diversão de jogos que possuem objetivos claros e definidos. }\end{array}$ \\
\hline Aluno 10 & O jogo é ótimo e cumpre com a proposta, mas poderia ter mais fases. \\
\hline Aluno 11 & $\begin{array}{l}\text { O jogo é ótimo. Consegui aprender bem os conceitos, mesmo não tendo feito a } \\
\text { disciplina de metodologia da pesquisa. }\end{array}$ \\
\hline Aluno 12 & $\begin{array}{l}\text { O jogo é divertido. Levei um pouco de tempo para me acostumar com os comandos, } \\
\text { mas não tive dificuldades para entender o seu funcionamento e o seu propósito. }\end{array}$ \\
\hline Aluno 13 & $\begin{array}{l}\text { Fazia algum tempo que eu não jogava. Mas achei o jogo bom, fácil e com propósitos } \\
\text { claros. No início, por falta de prática, tive alguma dificuldade com os comandos. } \\
\text { Depois, foi fácil. }\end{array}$ \\
\hline Aluno 15 & $\begin{array}{l}\text { O jogo é ótimo e cumpre com a proposta, mas poderia ter mais fases (por isso dei nota } \\
8,0) \text {. }\end{array}$ \\
\hline Aluno 16 & $\begin{array}{l}\text { O jogo é bem desafiador, divertido, com objetivos claros, mas poderia ter mais fases. É } \\
\text { "viciante". }\end{array}$ \\
\hline
\end{tabular}


Mesmo com uma etapa introdutória de familiarização com o jogo, dois participantes (13,33\%) sugeriram a composição de um manual de instruções e uma fase de treinamento, de modo que eles pudessem melhor se adaptar aos comandos do teclado. De todo modo, muitos foram os relatos apontando que as dificuldades nesse quesito foram apenas iniciais, confirmando que o tempo estabelecido para a sessão de interação com o Mundo da Metodologia foi suficiente para essa adaptação.

Entre os respondentes, três (20\%) classificaram o jogo como ótimo e dois (13,33\%) como muito bom. Além disso, o divertimento surgiu nas respostas de seis acadêmicos (40\%), bem como a afirmação de que o jogo cumpre com seus propósitos ou que estes ficam bem claros aos jogadores conforme o decorrer da partida.

Chama a atenção, também, o comportamento de resposta dos alunos 10, 15 e 16. Apesar de os três (20\%) terem sugerido que o jogo tivesse mais fases, este quesito representou uma quebra de expectativa para apenas um deles - fato que é confirmado pelo jogador ao justificar que sua nota 8,0 decorre dessa condição.

Embora essa relação seja conclusiva somente em um dos casos, o contexto evidenciou que a ampliação do jogo pode ser uma estratégia para potencializar a construção de um envolvimento emocional maior junto aos acadêmicos.

\section{Considerações finais}

O presente estudo apresentou o jogo Mundo da Metodologia como proposta de um instrumento digital voltado a apoiar a compreensão, composição e estruturação de dois elementos essenciais quando da elaboração de uma pesquisa científica: o objetivo geral e os objetivos específicos. Embasado nos princípios da DGBL, o game em questão foi desenvolvido com a finalidade de facilitar o processo de ensino-aprendizagem dos referidos conceitos dentro da disciplina de Metodologia da Pesquisa ou quaisquer outras que fizerem uso dos mesmos fundamentos nos planos teórico ou prático.

Do ponto de vista pedagógico, a DGBL proporciona uma nova dinâmica à construção do conhecimento ao colocar os estudantes como protagonistas ao longo do processo, levando-os a uma reflexão sobre o que está sendo aprendido na medida em que evoluem no jogo. E com inspiração na ideia de que o potencial da DGBL pode ser amplificado quando adotada em espaços híbridos, optou-se por inserir o Mundo da Metodologia em um ambiente com três distintas plataformas sequenciais como forma de avaliar suas contribuições no âmbito acadêmico.

Avaliando os desdobramentos deste estudo, a primeira percepção foi de que o game acrescentou componentes de descontração e ludicidade à sala de aula, permitindo aos alunos que se divertissem enquanto progrediam no processo de construção do conhecimento. E mesmo que a amostra, em sua maior parte, fosse formada por jogadores casuais, a introdução do jogo contribuiu eficientemente para que os participantes obtivessem êxito em ambas as plataformas empregadas para aferição do desempenho; possibilitando aos alunos que relacionassem assertivamente os conceitos explorados pelo Mundo da Metodologia e, consequentemente, atingissem um ótimo nível de aproveitamento quando da aplicação prática dos referidos fundamentos.

Dessa forma, é passível de constatação que o Mundo da Metodologia acompanhou o que é sustentado pelos autores que embasaram o presente artigo ao se mostrar um eficiente aporte tecnológico que ultrapassou a finalidade de contribuir com a consolidação das bases teóricas exploradas por ele dentro das disciplinas. O jogo oportunizou aos acadêmicos fazê-lo de forma clara, divertida e engajadora. Vale mencionar que isso também é perceptível através dos indicadores de validação que evidenciaram um alto grau de aprovação dos alunos quanto à aplicação do jogo para os objetivos propostos. Nessa acepção, destacam-se alguns índices com resultados $100 \%$ positivos, tais como: clareza quanto aos objetivos do jogo, clareza quanto aos princípios teóricos abordados e a forma que eles são contextualizados pelo game.

É importante ressaltar que o alcance das contribuições aqui elencadas deu-se através de um quase-experimento que apresentou a evolução de uma amostra formada por acadêmicos com 
nenhum conhecimento sobre os preceitos teóricos mediados, não havendo, portanto, qualquer parâmetro que viabilize contrastar a performance entre usuários de diferentes plataformas para desenvolver os mesmos conceitos. Assim, propõe-se como trabalho futuro a realização de um estudo comparativo cujo objetivo é avaliar o grau de desempenho entre acadêmicos quando mediados por diferentes plataformas.

A pesquisa, que terá um caráter experimental, deverá contar com alunos distribuídos em dois grupos de controle: um em que os estudantes buscarão a construção do conhecimento mediados pelo Mundo da Metodologia e outro em que o processo se dará através de plataformas analógicas. Além do índice de assertividade, o tempo despendido para a realização das atividades estará entre os parâmetros observados para apuração da performance individual dos participantes do experimento.

\section{Referências}

AGUIAR, J. S. Educação Inclusiva: jogos para o ensino de conceitos. Campinas: Papirus, 40 edição, 2008.

ALVES, E. M. S. A Ludicidade e o Ensino da Matemática. Campinas: Papirus, $4^{\circ}$ edição, 2007.

ALVES, F. S. Gamification: como criar experiências de aprendizagem engajadoras. São Paulo: DVS Editora, 2014.

ALVES, L. Jogos Eletrônicos e Screenagers: possibilidades de desenvolvimento e aprendizagem. In: SANTOS, E.; ALVES, L. (org.). Práticas Pedagógicas e Tecnologias Digitais. Rio de Janeiro: E-papers, p.143-160, 2006.

ANTUNES, C. Jogos para Estimulação das Múltiplas Inteligências. Petrópolis: Editora Vozes, 190 edição, 2012. 2017.

O Jogo e a Educação Infantil: falar e dizer, olhar e ver, escutar e ouvir. Petrópolis: Editora Vozes,

BELL, M. W; ROSBINS-BELL, S. Para uma Definição Expandida de "Mundos Virtuais". In: VILARRES, F. (org.). Novas Mídias Digitais (Audiovisual, Games e Música): impactos políticos, econômicos e sociais. Rio de Janeiro: E-Pappers, p.135-144, 2008.

BONATTI, D. Desenvolvimento de Jogos em HTML5. Rio de Janeiro: Brasport, 2014.

BOLER, S.; KAPP, K. Jogar para Aprender: tudo o que você precisa saber sobre o design de jogos de aprendizagem eficazes. São Paulo: DVS Editora, 2018.

BURKE, B. Gamificar: como a gamificação motiva as pessoas a fazerem coisas extraordinárias. São Paulo: DVS Editora, 2015.

BUSARELLO, R. I. Gamification: princípios e estratégias. São Paulo: Pimenta Cultural, 2016.

CARRAmenhA, P. Administrando o Processo de Pesquisa. In: PERdigÃo, D. M.; HeRLinger, M.; WHITE, O. M. (org.). Teoria e Prática da Teoria Aplicada. Rio de Janeiro: Elsevier, cap. 40, 2012.

CARVALHO, C. V. Aprendizagem Baseada em Jogos. In: II Word Congress on System Engeneering and Information Technology: challenges, practices and technologies in the era of information. Vigo: Anais do Evento, p.176-181, 2015.

CHAGAS, C. P. Tecnologias e Cognição: aprimorando habilidades e saberes docentes com jogos digitais. Curitiba: Appirs, 10 edição, 2018.

CHANDLER, H. M. Manual de Produção de Jogos Digitais. Porto Alegre: Bookmann, $2^{\circ}$ edição, 2011.

CID, E. F. K. O Uso dos Jogos como Estratégia Motivadora no Processo de Ensino e Aprendizagem da Educação Profissional. Vitória: Cousa, 2017. 
COSTA, L. D. O que os Jogos de Entretenimento Têm que os Educativos Não Têm: sete princípios para projetar jogos educativos eficientes. Rio de Janeiro: Novas Ideias, 2010.

DURAZZO, L.; BADIA, D. D. Dinâmicas da Alteridade: o role playing game (RPG) como narrativa do imaginário. In: MONTEIRO, S.; RIBEIRO, R.; LEMES, S. S.; MUZZETI, L. R. (org.). Educações na Contemporaneidade: reflexão e pesquisa. São Carlos: Joao \& Pedro Editores, p. 141-162, 2011.

HUIZINGA, J. Homo Ludens. São Paulo: Perspectiva, $4^{0}$ edição, 2000.

KELLY, K. Inevitável: as 12 forças tecnológicas que mudarão o nosso mundo. São Paulo: HSM, 2017.

KENSKI, V. M. Educação e Tecnologias: o novo ritmo da informação. Campinas: Papirus, 2003.

LIMA, E. R. P. O.; MOITA, F. M. G. S. C. A Tecnologia e o Ensino de Química: jogos digitais como interface metodológica. In: SOUZA, R. P.; MOITA, F. M. G. S. C.; CARVALHO, A. B. G. (org.). Tecnologias Digitais na Educação. Campina Grande: EDUEPB, p. 131-154, 2011.

MACEDO, L.; PETTY, A. L. S.; PASSOS, N. C. Os Jogos e o Lúdico na Aprendizagem Escolar. Porto Alegre: Artmed, 2007.

MARINACCI, J. Construindo Aplicativos Móveis com Java. São Paulo: Novatec Editora, 2012.

MATTAR, J. Games em Educação: como os nativos digitais aprendem. São Paulo, Pearson Prentice Hall, 2010.

MOITA, F. M. G. S. C. Design Metodológico para Avaliar o Game Angry Birds Rio e Evidências da Utilização em Sala de Aula. In: ALVES, L.; COUTINHO, I. J. (org.). Jogos Digitais e Aprendizagem: fundamentos para uma prática baseada em evidências. Campinas: Papirus, p. 163-178, 2017.

OLIVEIRA, M. M. Como Fazer Projetos, Relatórios, Monografias, Dissertações e Teses. Rio de Janeiro: Elsevier, $5^{\circ}$ edição, 2011.

PRODANOV, C. C.; FREITAS, E. C. Metodologia do Trabalho Científico: métodos e técnicas da pesquisa e do trabalho acadêmico. Novo Hamburgo: Feevale, $2^{\circ}$ edição, 2013.

SANTOS, G. R. C. M.; MOLINA, N. L.; DIAS, V. F. Orientações e Dicas Práticas para Trabalhos Acadêmicos. Curitiba: Ibpex, 2007.

SCHLEMMER, E.; LOPEZ, D.Q. Avaliação da Aprendizagem em Processos Gamificados: desafios para apropriação do método cartográfico. In: ALVES, L.; COUTINHO, I. J. (org.). Jogos Digitais e Aprendizagem: fundamentos para uma prática baseada em evidências. Campinas: Papirus, p. 179-208, 2017.

TOGNERI, D. F.; LORENZONI, L. L. Inteligência Artificial para Jogos. In: AZEVEDO, E. (Coord.). Desenvolvimento de Jogos 3D e Aplicações de Realidade Virtual. Rio de Janeiro: Elsevier, cap. 7, 2005.

TOZONI-REIS, M. F. C. Metodologia da Pesquisa. Curitiba: IESDE Brasil, $2^{\circ}$ edição, 2010. 


\section{Márcio da Cunha Marins}

Centro Universitário Uniftec/FGV - Campus Caxias do Sul, Brasil, marciomarins@ftec.com.br

\section{Evandro Manara Miletto}

Programa de Pós-Graduação em Informática na Educação - Instituto Federal de Educação, Ciência de Tecnologia do Rio Grande do Sul - IFRS - Campus Porto Alegre , Brasil, evandro.miletto@poa.ifrs.edu.br 